\title{
Skrining Senyawa Metabolit Sekunder Ekstrak Metanol Biji Alpukat (Persea Americana Mill.) Asal Pulau Timor
}

\author{
Aloisius M. Kopon; Anselmus B. Baunsele; Erly G. Boelan. \\ ${ }^{1}$ Pendidikan Kimia, Universitas Katolik Widya, Mandira, Kupang, NTT \\ *Corresponding author: earlygrizca@gmail.com
}

\begin{abstract}
Avocados (Persea americana Mill.) have many benefits for traditional medicine especially in East Nusa Tenggara. The purpose of this study was to analyze the secondary metabolite compounds contained in avocado seeds and to identify groups compounds in avocado seeds extract. The research method used was maceration of samples for 3 days and continued with phytochemical dan FT-IR test. The result showed that methanol extract of avocado seeds contains phytochemicals based on test result of secondary metabolites, the alkaloids, flavonoids, steroids, terpenoids, saponins and tannins. While the results of FT-IR analysis showed the presences of $\mathrm{OH}, \mathrm{CH}, \mathrm{C}=\mathrm{C}$, and $\mathrm{C}$ - $\mathrm{O}$ groups.
\end{abstract}

Keywords: avocado seed (Persea Americana Mill.), methanol extract, phytochemical screening, FT-IR.

\begin{abstract}
Abstrak
Alpukat merupakan salah jenis tanaman yang digunakan oleh masyarakat Indonesia khususnya Nusa Tenggara Timur sebagai obat tradisional. Penelitian ini bertujuan untuk mengetahui metabolit sekunder yang terdapat pada biji alpukat dan juga mengetahui gugus dan jenis ikatan. Metode penelitian yang dilakukan adalah maserasi sampel selama 3 hari dan dilajutkan dengan uji fitokimia dan FT-IR. Hasil skrining fitokimia, menunjukan bahwa ekstrak metanol biji alpukat mengandung senyawa metabolit sekunder diantaranya alkaloid, flavonoid, saponin, tanin, triterpenoid dan steroid. Sedangkan hasil analisis FT-IR yang menunjukan adanya gugus $\mathrm{OH}, \mathrm{CH}, \mathrm{C}=\mathrm{C}$, dan $\mathrm{C}$-O .
\end{abstract}

Kata kunci: biji alpukat, ektrak metanol, skrining fitokimia, skrining fitokimia, FT-IR

I. Pendahuluan

Indonesia merupakan negara tropis yang kaya akan keanekaragaman hayati. Salah satu tanaman yang tumbuh subur dan tersebar di Indonesia adalah alpukat (Persea americana Mill.). Alpukat merupakan tanaman yang berasal dari Amerika Tengah dan dapat tumbuh pada daerah tropis seperti di daratan pulau Timor. Daun, kulit batang, daging buah, biji hingga akar tanaman ini 
memiliki banyak manfaat dalam kehidupan sehari-hari salah satunya adalah sebagai tanaman obat.

Penggunaan alpukat sebagai tanaman obat telah digunakan secara luas. Masyarakat Nusa Tenggara Timur (NTT) biasanya menggunakan biji buah alpukat sebagai obat tradisional diantaranya untuk mengatasi sembelit, menyembuhkan radang, menjaga daya tahan tubuh dan juga untuk mengobati penyakit gula darah/diabetes melitus. Cara menggunakan biji alpukat untuk pengobatan secara tradisonal adalah dengan merebus potongan biji alpukat dengan air dan kemudian langsung dikonsumsi. Berdasarkan penelitian sebelumnya biji buah alpukat yang memiliki berat kurang lebih $16 \%$ dari total berat buah ini memiliki banyak manfaat dalam bidang kesehatan, yaitu diantaranya sebagai antikanker, antiinflamasi, antidiabetes, penurun tekanan darah, serta antimikroba [1].

Tanaman obat tradisional yang sering digunakan oleh masyrakat diketahui memiliki potensi untuk dikembangkan lebih lanjut pada bidang farmakologi. Hal ini tentunya harus dibuktikan dengan berbagai pengujian serta identifikasi senyawa kimia yang terdapat pada tumbuhan tersebut. Berdasarkan hasil penelitian sebelumnya dilaporkan bahwa biji alpukat mengandung senyawa metabolit sekunder diantaranya flavonoid, steroid, terpenoid, saponin, tanin, glikosida kardiak serta alkaloid [2]. Selain itu pada penelitian lainnya Abe, dkk [3] melaporkan bahwa dalam ekstrak metanol biji alpukat mengandung 2 senyawa turunan 1,24-trihidroksi nanodekana dan 6 senyawa turunan 1,2,4-trihidroksi dekana yang memiliki potensi sebagai antiinsektisida. Akan tetapi letak geografis, suhu, iklim dan kesuburan tanah suatu wilayah dapat menentukan kandungan kimia dalam suatu tanaman. Pada tanaman yang sama jenisnya, kandungan senyawa kimia dapat berbeda antara satu daerah dengan daerah lainnya. Oleh karena itu studi dan riset awal terhadap ekstrak biji alpukat yang berasal dari pulau Timor perlu dilakukan.

\section{Metodologi}

\section{Alat dan Bahan}

Alat dan instrument yang digunakan dalam penelitian ini adalah Erlenmeyer, corong, evaporator, batang pengaduk, tabung rekasi, pipet tetes, gelas kimia, neraca analitik, plat tetes, dan FT-IR.

Bahan-bahan yang digunakan dalam penelitian ini adalah biji alpukat, Metanol PA 96\%, aquades, HCL, reagen Mayer, reagen Wagner, pita magnesium, $\mathrm{FeCl}_{3}$, asam asetat anhidrat 98\%, asam sulfat 98\%, dan Kloroform $98 \%$

\section{Ekstrak Biji Alpukat}

Sebanyak $50 \mathrm{~g}$ biji alpukat yang telah dihaluskan dimaserasi dengan menggunakan methanol selama 3x24 jam. Ekstrak disaring 
dan disimpan selama 14 hari kemudian dievaporasi dan diperoleh ekstrak kental

\section{Uji Komponen Fitokimia Ekstrak Biji} Alpukat

Uji alkaloid dilakukan dengan menggunakan reagen Mayer dan Wagner. Sebanyak 0,01 mg ekstrak dimasukan ke tabung $\mathrm{A}$ dan $\mathrm{B}$, dan ditambahkan $0,5 \mathrm{~mL}$ $\mathrm{HCl} 2 \%$ pada tabung A dan dikocok hingga homogen. Kemudian ditambahkan 2-3 tetes reagen Mayer ke dalam tabung A dan 2-3 tete reagen Wagner ke dalam tabung B. jika terbentuk endapan putih pada tabung A dan endapan coklat pada tabung B maka sampel tersebut mengandung alkaloid [4].

Uji kandungan Flavonoid dilakukan dengan cara memasukan $0.01 \mathrm{mg}$ ekstrak ke dalam tabung reaksi dan ditambahkan dengan air panas secukupnya. Filtrat yang ada diambil sebanyak $5 \mathrm{~mL}$ dan ditambahkan 2 $\mathrm{cm}$ pita $\mathrm{Mg}$ dan $1 \mathrm{~mL} \mathrm{HCl}$ pekat kemudian dikocok. Jika terbentuk warna merah, kuning atau jingga, menunjukkan adanya flavonoid [5].

Uji saponin pada ekstrak yang ada dilakukan metode Forth. $0.01 \mathrm{mg}$ ekstrak dimasukan ke dalam tabung reaksi setelah itu ditambahkan $2 \mathrm{~mL}$ air panas. Sampel akan terbentuk busa kemudian ditambahkan $1 \mathrm{~mL}$ $\mathrm{HCl} 2 \mathrm{~N}$. Jika busa tersebut tidak hilang selama 30 detik maka ekstrak positif mengandung saponin [4], [6].
Pengujian adanya Tanin pada esktrak dilakukan dengan menambahkan beberapa tetes larutan besi (III)klorida $10 \%$ ke dalam 1 ml ekstrak. Apabila terbentuk endapan berwarna biru tua atau hitam kehijauan maka ekstrak positif mengandung tannin [5].

Pengujian adanya Triterpenoid dan Steroid pada sampel ekstrak biji alpukat didahului dengan mencampur $0.01 \mathrm{mg}$ ekstrak dengan $2 \mathrm{~mL}$ kloroform $98 \%$ di dalam tabung reaksi kemudian dikocok. Setelah itu lapisan kloroform yang terbentuk diambil dan diteteskan ke plat tetes dan biarkan sampai kering, kemudian ditambahkan 5 tetes asam asetat anhidrat $98 \%$ dan 3 tetes $\mathrm{H}_{2} \mathrm{SO}_{4} 98 \%$. Jika terbentuk warna merah, orange, kuning maka sampel mengandung triterpenoid dan jika terbentuk warna hijau sampel mengandung steroid [4].

\section{Hasil dan Pembahasan}

Ekstraksi merupakan proses pemisahan suatu zat berdasarkan perbedaan kelarutan terhadap dua atau lebih zat yang tidak tercampur. Ekstraksi biji alpukat dilakukan dengan metode maserasi menggunakan pelarut metanol dan menghasilkan rendemen sebesar $10,03 \%$ dengan perbandingan 1:4 (200 g sampel:800 $\mathrm{mL}$ pelarut metanol). Hasil rendemen suatu sampel sangat bergantung pada sifat kelarutan komponen bioaktif [7]. Pemecahan dinding dan membran sel oleh metanol menyebabkan 
komponen senyawa polar dalam ekstrak biji alpukat larut dalam metanol

\section{Uji Fitokimia}

Hasil pengujian fitokimia terhadap ekstrak metanol biji alpukat dilakukan untuk mengetahui senyawa metabolit sekunder yang terdandung. Hasil uji fitikomia dapat dilihat pada Tabel 1. Hasil pengujian menunjukan bahwa ekstrak metanol biji alpukat mengandung golongan senyawa alkaloid, flavonoid, saponin, tanin, triterpenoid dan steroid. Hasil ini sesuai dengan penelitian yang dilakukan sebelumnya ([2], [8]) yang melakukan identifikasi metabolit sekunder pada ekstrak metanol dan etil asetat biji alpukat.

Tabel 1. Hasil Uji Fitokimia pada ekstrak methanol biji alpukat

\begin{tabular}{lcl}
\hline \multicolumn{1}{c}{$\begin{array}{c}\text { Golongan } \\
\text { Senyawa }\end{array}$} & $\begin{array}{c}\text { Hasil } \\
\text { Uji }\end{array}$ & \multicolumn{1}{c}{ Keterangan } \\
\hline Alkaloid & & \\
Reagen Mayer & + & $\begin{array}{l}\text { Terbentuk endapan } \\
\text { putih } \\
\text { Reagen Wagner }\end{array}$ \\
& + & $\begin{array}{l}\text { Terbentuk endapan } \\
\text { cokelat }\end{array}$ \\
Flavonoid & + & $\begin{array}{l}\text { Larutan berwarna } \\
\text { coklat kemerahan } \\
\text { Busa stabil }\end{array}$ \\
Saponin & + & $\begin{array}{l}\text { Larutan berwarna } \\
\text { biru tua } \\
\text { Tanin }\end{array}$ \\
Triterpenoid/ & + & $\begin{array}{l}\text { Larutan berwarna } \\
\text { kemerahan dan }\end{array}$ \\
Steroid & & hijau \\
\hline
\end{tabular}

Pada pengujian alkaloid hasil positif ditunjukan dengan adanya endapan putih saat direaksikan dengan reagen Mayer dan endapan cokelat saat direaksikan dengan reagen Wagner. Terbentuknya endapan ini disebabkan karena adanya pergantian ligan. Senyawa alkaloid bersifat semi polar yang mengandung atom nitrogen pada bagian sikliknya serta mengandung beberapa subtituen yang bervariasi seperti gugus amnina, amida metoksi, serta fenol [9]. Perkiraan reaksi yang terjadi pada uji alkaloid dengan menggunakan pereaksi Mayer dapat dilihat pada Gambar 1. Pada saat pembuatan pereaksi akan terbentuk endapan merah $\mathrm{HgI}_{2}$ sebagai hasil reaksi antara larutan $\mathrm{HgCl}_{2}$ dan KI. Dan apabila KI yang ditambahkan berlebih maka akan menghasilkan $\mathrm{K}_{2}\left[\mathrm{HgI}_{4}\right]$. Sehingga ketika direaksikan pada sampel, senyawa alkaloid yang memiliki atom nitrogen akan beraksi dengan ion logam $\mathrm{K}^{+}$dari $\mathrm{K}_{2}\left[\mathrm{HgI}_{4}\right]$ dan membentuk endapan kompleks kaliumalkaloid.

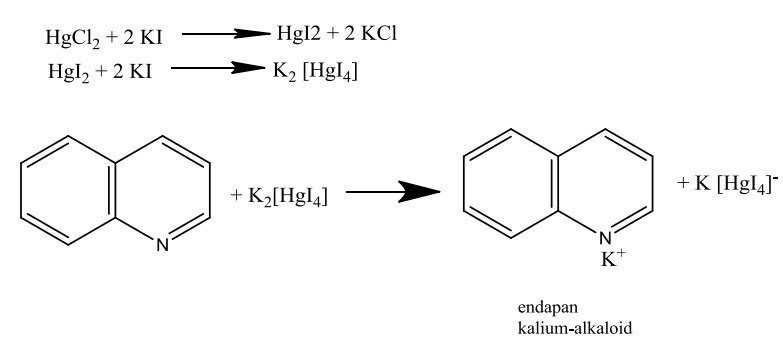

Gambar 1. Perkiraan Reaksi Uji Alkaloid Pereaksi Mayer [15]

Sedangkan untuk reaksi uji alkaloid dengan menggunakan pereaksi Wagner dapat dilihat pada Gambar 2. Pereaksi Wagner terdiri dari 
$\mathrm{KI}$ dan $\mathrm{I}_{2}$ yang dapat bereaksi membentuk $\mathrm{I}_{3}{ }^{-}$ yang berwarna cokelat. Pada saat direaksikan ion logam $\mathrm{K}^{+}$membentuk kompleks kaliumalkaloid yang menghasilkan endapan.<smiles></smiles>

Gambar 2. Perkiraan Reaksi Uji Alkaloid Pereaksi Wagner [15]
Pada uji flavonoid digunakan $\mathrm{Mg}$ dan HCl. Hasil menunjukan positif ditandai dengan terbentuknya warna coklat kemerahan yang menandakan terjadinya reduksi. Perkiraan reaksi yang terjadi pada uji flavonoid dapat dilihat pada Gambar 3. Adanya gugus hidroksi pada golongan senyawa flavonoid menunjukan bahwa golongan senyawa ini cenderung bersifat polar.

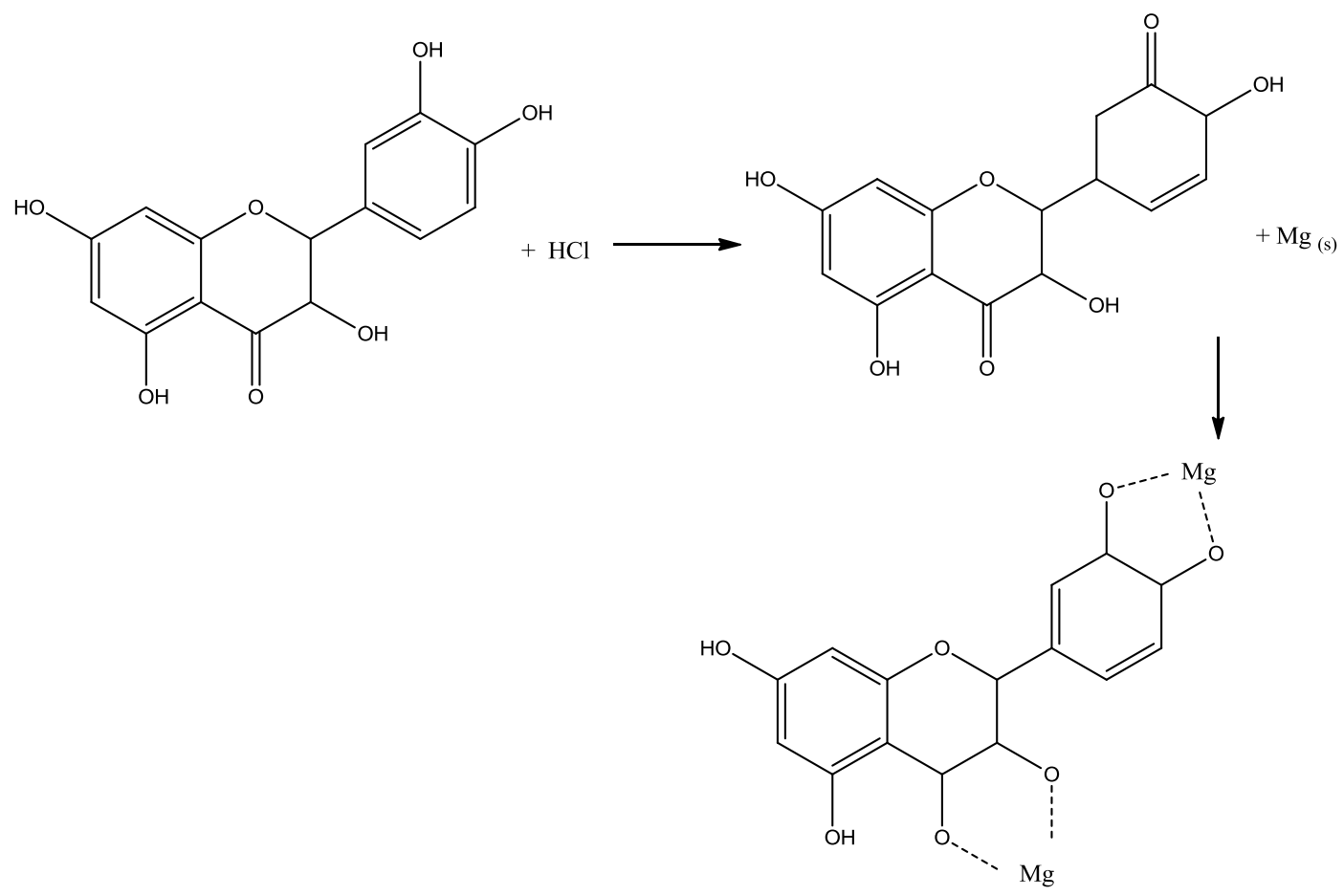

Gambar 3. Perikiraan Reaksi Uji Flavonoid [10]

Hal yang sama juga terjadi pada golongan senyawa tanin. Senyawa ini cenderung bersifat polar karena memiliki gugus hidroksi. Identifikasi terhadap senyawa tanin dilakukakan melalui penambahan $\mathrm{FeCl}_{3}$ dan Sampel menunjukan perubahan warna menjadi biru kehitaman yang menunjukan bahwa senyawa tanin mengalami hidrolisis. Reaksinya dapat dinyatakan sebagai berikut:

$\mathrm{FeCl}_{3}(\mathrm{aq})+6 \mathrm{ArOH}(\mathrm{s}) \rightarrow 6 \mathrm{H}^{+}+3 \mathrm{Cl}^{-}+[\mathrm{Fe}$ $\left.(\mathrm{OAr})_{6}\right]^{3-}(\mathrm{aq})[10]$

Saponin merupakan senyawa aktif permukaan yang mudah terdeksi melalui kemampuannya membentuk busa. Pengujian golongan senyawa saponin pada ekstrak biji 
alpukat ditandai dengan adanya busa yang stabil. Golongan senyawa saponin mengandung gugus glikosil yang bersifat polar dan gugus steroid dan triterpenoid yang bersifat non polar. Senyawa yang memiliiki gugus non polar dan polar akan bersifat aktif dipermukaan. Reaksi pembentukan busa pada uji saponin ditunjukkan pada Gambar 4. Timbulnya buih menunjukkan adanya glikosida yang memiliki kemampuan membentuk buih dalam air yang terhidrolisis menjadi glukosa dan senyawa lain.

Uji triterpenoid/steroid berdasar pada kemampuan senyawa tersebut membentuk warna $\mathrm{H} 2 \mathrm{SO} 4$ pekat dalam pelarut asam asetat anhidrida [4], [9]. Prinsip dari rekasi ini adalah pelepasan $\mathrm{H}_{2} \mathrm{O}$ dan penggabungan dengan karbokation. Hasil penelitian menunjukan bahwa ekstrak biji alpukat mengandung triterpenoid dengan terbentuknya warna merah dan positif mengandung steroid dengan terbentuknya warna hijau.

Idris, dkk [2] juga pernah melakukan uji fitokimia terhadap biji alpukat dengan menggunakan beberapa pelarut yaitu metanol, etil asetat, kloroform dan petroleum eter. Ekstrak metanol dan etil asetat menunjukan hasil positif terhadap flavonoid, steroid, terpenoid, saponin, tanin, alkaloid dan karbohidrat; dan negatif terhadap antrakuinon dan glikosida sianogen. Ekstrak kloroform menunjukan hasil positif terhadap steroid, terpenoid, saponin dan alkaloid; dan negatif terhadap flavonoid, tanin, antrakuinon, glikosida sianogen dan karbohidrat. Sedangkan ekstrak petroleum eter menunjukan hasil positif terhadap steroid, terpenoid dan saponin; dan negatif terhadap flavonoid, tanin, antrakuinon, alkaloid dan glikosida sianogen.
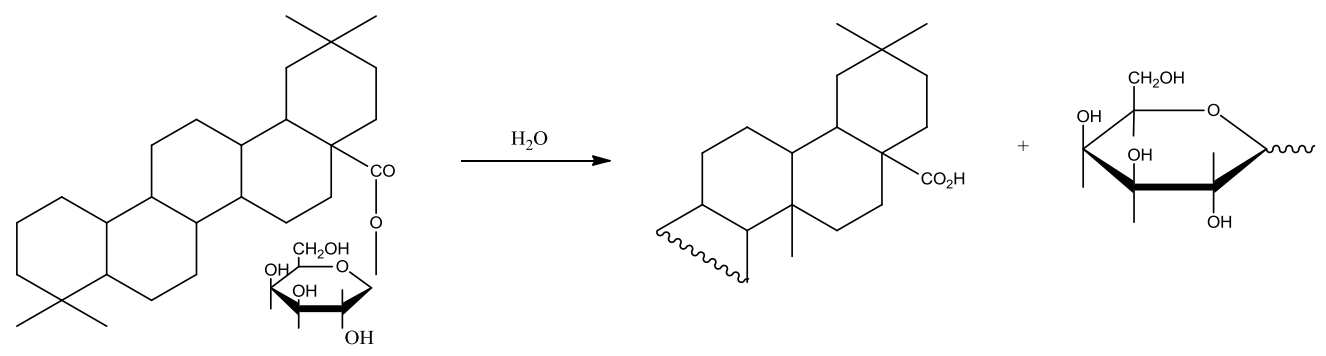

Gambar 4. Perkiraan Reaksi Uji Saponin [15]

Analisis Spektriskopi Infra Merah (FTIR)

\section{Ekstrak Biji Metanol}

Sampel ekstrak metanol biji alpukat selanjutnya diuji dengan menggunakan spektofotometer FT-IR dengan tujuan untuk mengetahui gugus atau jenis ikatan dari suatu senyawa berdasarkan nilai serapan pada bilangan gelombang tertentu. Data hasil uji FT-IR dapat dilihat pada Tabel 2.

Spektrum IR senyawa yang terdapat dalam ekstrak biji alpukat memberikan 
infromasi adanya puncak serapan gugus hidroksil pada bilangan gelombang 3419,24 $\mathrm{cm}^{-1}$. Gugus hidroksil ini merupakan regang $\mathrm{OH}$ terikat, yang membentuk pita lebar dengan intensitas yang kuat. Puncak lebar yang terbentuk pada bilangan gelombang $3419,24 \mathrm{~cm}^{-1}$ ini terbentuk sebagai akibat adanya vibrasi antarmolekul hidrogen.

Serapan pada bilangan gelombang 2926,35 $\mathrm{cm}^{-1}$ dan 2854,37 $\mathrm{cm}^{-1}$ dengan intensitas medium menunjukan adanya $\mathrm{CH}$ alifatik. Dugaan ini diperkuat dengan adanya serapan pada bilangan gelombang 1441,43 $\mathrm{cm}^{-1}$ dan 1384,42 $\mathrm{cm}^{-1}$ yang merupakan gugus $\mathrm{CH}$ alifatik. Pada bilangan gelombang $1654,41 \mathrm{~cm}^{-1}$ dengan bentuk peak lancip menunjukan adanya gugus $-\mathrm{C}=\mathrm{C}$. Ikatan $-\mathrm{C}$ $\mathrm{O}$ aromatik muncul pada bilangan gelombang $1059,40 \mathrm{~cm}^{-1}$

Pola lokasi bilangan gelombang, bentuk dan intensitas spektra pada penelitian ini hampir mirip dengan beberapa penelitian yang telah dilakukan sebelumnya. Tabel 2 juga menunjukkan perbandingan hasil analisis spektra IR biji alpukat dengan beberapa penelitian terdahulu. Retnosari, dkk [11] melakukan analisis spektrum IR terhadap isolat ekstrak metanol biji alpukat pada komponen K-1 yang menunujkan bahwa isolat tersebut mengandung gugus $\mathrm{OH}, \mathrm{C}=\mathrm{O}$, ikatan $\mathrm{C}-\mathrm{H}$ dan ikatan $\mathrm{C}=\mathrm{C}$. Penelitian lainnya yang dilakukan oleh Abubakar dkk [12] menunjukan bahwa pada isolat ekstrak etanol biji alpukat mengandung gugus $\mathrm{OH}, \mathrm{CH}, \mathrm{C}=\mathrm{O}, \mathrm{C}=\mathrm{C}, \mathrm{C}-\mathrm{C}$ dan $\mathrm{C}-\mathrm{O}$. Feliana, dkk [13] yang menganalisis isolat biji alpukat dari yang di ekstrak menggunakan pelarut etil asetat dimana isolat yang dianalisis dengan FT-IR menghasilkan gugus $\mathrm{OH}, \mathrm{C}=\mathrm{O}, \mathrm{C}-\mathrm{H}$ aromatik dan alifatik, $\mathrm{C}=\mathrm{C}$ dan $\mathrm{C}-\mathrm{O}$.

Secara umum Pada penelitian ini tidak terlihatnya ada gugus $\mathrm{C}=\mathrm{O}$ dan $\mathrm{C}-\mathrm{C}$ hal ini diduga karena jenis sampe yang digunakan untuk analisis masih berupa ekstrak kasar, tanpa melalui fraksinasi dan purifikasi. Dalam ekstrak kasar masih terkandung beberapa senyawa yang mengakibatkan kadar senyawa target relatif rendah sehingga membuat absorbsi gugus atom terhadap inframera sangat rendah. Akibatnya puncak senyawa target tidak muncul dan terjadi peaks overlapping dalam spektra tersebut.

Gugus fungsional hidroksil (-OH), eter (R-OR') dan keton (R-CO-R') merupakan gugus fungsional yang banyak terdapat pada senyawa golongan alkaloid, fenol/polifenol, flavonoid, saponin, dan terpenoid; dan alkana sebagai karbon alifatisnya. Hal ini dikuatkan dengan uji fitokimia yang telah dilakukan bahwa ekstrak biji alpukat positif mengandung golongan senyawa alkaloid, flavonoid, tanin, saponin, triterpenoid dan steroid.

Dalam bidang kesehatan kelompok senyawa alkaloid berperan sebagai 
antihipertensi dan antidiabetes. Selain alkaloid, kelompokk senyawa flavonoid juga memiliki khasiat sebagai antihipertensi Kandungan flavonoid dan tannin yang terdapat pada sampel menunjukan bahwa biji alpukat memiliki potensi sebagai antioksidan. Selain itu penelitian yang dilakukan oleh Retnosari dkk [11], menujukan bahwa ekstrak metanol biji alpukat pada fraksi 4 dan komponen K-1 memiliki aktivitas sabagai antibakteri ketika diujikan pada Escherichia coli dan Staphylococcus aureus dimana berdasarkan hasil anlisis yang dilakukan komponen K-1 merupakan golongan saponin. Dalam struktur senyawa metabolit sekunder, hampir semua senyawa memliki gugus hidroksi (OH) yang berperan terhadap aktivitas biologis makhluk hidup. Kemampuan membentuk ikatan hidrogren oleh suatu senyawa aktif mengakibatkan senyawa tersebut mudah larut dalam air serta dengan mudah berinteraksi dengan protein target dalam suatu organisme [14].

Tabel 2. Perbandingan Hasil Analisis Spektroskopi IR Biji Alpukat dengan Beberapa Penelitian Sebelumnya

\begin{tabular}{|c|c|c|c|c|c|c|c|c|c|}
\hline \multicolumn{2}{|c|}{$\begin{array}{c}\text { Sampel } \\
\text { Ekstrak Metanol }\end{array}$} & \multicolumn{2}{|c|}{$\begin{array}{c}\text { Isolat Ekstrak Metanol } \\
{[11]}\end{array}$} & \multicolumn{2}{|c|}{$\begin{array}{l}\text { Isolat Ekstrak Etanol } \\
{[12]}\end{array}$} & \multicolumn{2}{|c|}{$\begin{array}{c}\text { Isolat Ekstrak } n \text {-hexan } \\
\text { \& Etanol [13] }\end{array}$} & \multicolumn{2}{|c|}{$\begin{array}{c}\text { Isolat Ekstrak Etil } \\
\text { Asetat [8] }\end{array}$} \\
\hline $\begin{array}{c}\text { Bilangan } \\
\text { Gelombang } \\
\left(\mathrm{cm}^{-1}\right)\end{array}$ & $\begin{array}{l}\text { Interpre } \\
\text { tasi }\end{array}$ & $\begin{array}{c}\text { Bilangan } \\
\text { Gelombang } \\
\left(\mathrm{cm}^{-1}\right)\end{array}$ & $\begin{array}{l}\text { Interpret } \\
\text { asi }\end{array}$ & $\begin{array}{c}\text { Bilangan } \\
\text { Gelombang } \\
\left(\mathrm{cm}^{-1}\right)\end{array}$ & $\begin{array}{c}\text { Interpre } \\
\text { tasi }\end{array}$ & $\begin{array}{c}\text { Bilangan } \\
\text { Gelombang } \\
\left(\mathrm{cm}^{-1}\right)\end{array}$ & $\begin{array}{l}\text { Interpre } \\
\text { tasi }\end{array}$ & $\begin{array}{c}\text { Bilangan } \\
\text { Gelombang } \\
\left(\mathrm{cm}^{-1}\right)\end{array}$ & $\begin{array}{l}\text { Interpre } \\
\text { tasi }\end{array}$ \\
\hline 3419,24 & $-\mathrm{OH}$ & 3313,17 & $-\mathrm{OH}$ & 3444,87 & $-\mathrm{OH}$ & 3314,54 & $-\mathrm{OH}$ & 3309,85 & $-\mathrm{OH}$ \\
\hline 2926,35 & $\begin{array}{l}\text { C-H } \\
\text { Alifatik }\end{array}$ & 2920,23 & $\begin{array}{l}\text { C-H } \\
\text { Alifatik }\end{array}$ & 2926,01 & $\begin{array}{l}\text { C-H } \\
\text { Alifatik }\end{array}$ & 2926,24 & $\begin{array}{l}\text { C-H } \\
\text { Alifatik }\end{array}$ & 3080,32 & $\begin{array}{l}\text { C-H } \\
\text { Aromati } \\
\mathrm{k}\end{array}$ \\
\hline 2854,37 & $\begin{array}{l}\text { C-H } \\
\text { Alifatik }\end{array}$ & 1722,43 & $\mathrm{C}=\mathrm{O}$ & 2852,72 & $\begin{array}{l}\text { C-H } \\
\text { Alifatik }\end{array}$ & 2856,53 & $\begin{array}{l}\text { C-H } \\
\text { Alifatik }\end{array}$ & 2922,16 & $\begin{array}{l}\text { C-H } \\
\text { Alifatik }\end{array}$ \\
\hline 1654 & $\mathrm{C}=\mathrm{C}$ & 1650 & $\mathrm{C}=\mathrm{C}$ & 1737,86 & $\begin{array}{l}\mathrm{C}=\mathrm{O} \\
\text { (Ester) }\end{array}$ & 1721,26 & $\begin{array}{l}\mathrm{C}=\mathrm{O} \\
\text { (karbok } \\
\text { silat } \\
\text { atau } \\
\text { keton) }\end{array}$ & 2850,79 & $\begin{array}{l}\text { C-H } \\
\text { Alifatik }\end{array}$ \\
\hline 1441,43 & $\begin{array}{l}\mathrm{C}-\mathrm{H} \\
\text { pada } \\
\mathrm{CH}_{2}\end{array}$ & & & 1645,28 & $\mathrm{C}=\mathrm{C}$ & 1609,27 & $\mathrm{C}=\mathrm{C}$ & 1739,79 & $\begin{array}{l}\mathrm{C}=\mathrm{O} \\
\text { (Karbon } \\
\text { il) }\end{array}$ \\
\hline 1384,42 & $\begin{array}{l}\mathrm{C}-\mathrm{H} \\
\text { pada } \\
\mathrm{CH}_{3}\end{array}$ & & & 1462,04 & $\begin{array}{l}\mathrm{C}-\mathrm{H} \\
\text { pada } \\
\mathrm{CH}_{2}\end{array}$ & 1236,26 & $\mathrm{C}-\mathrm{O}$ & 1645,28 & $\mathrm{C}=\mathrm{C}$ \\
\hline 1059,40 & $\mathrm{C}-\mathrm{O}$ & & & 1384,89 & $\begin{array}{l}\mathrm{C}-\mathrm{H} \\
\text { pada } \\
\mathrm{CH}_{3}\end{array}$ & 1066 & $\mathrm{C}-\mathrm{O}$ & 1109,07 & $\mathrm{C}-\mathrm{O}$ \\
\hline & & & & 1165,00 & $\mathrm{C}-\mathrm{C}$ & & & 846,75 & $\begin{array}{l}\mathrm{C}-\mathrm{H} \\
\text { subtitusi }\end{array}$ \\
\hline & & & & 1107 & $\mathrm{C}-\mathrm{O}$ & & & & \\
\hline
\end{tabular}




\section{Kesimpulan}

Hasil skrining fitokimia, menunjukan bahwa ekstrak metanol biji alpukat mengandung senyawa metabolit sekunder diantaranya alkaloid, flavonoid, saponin, tanin, triterpenoid dan steroid. Data ini juga didukung oleh hasil analisis FT-IR yang menunjukan adanya gugus $\mathrm{OH}, \mathrm{CH}, \mathrm{C}=\mathrm{C}$, dan C-O.

\section{Ucapan Terima Kasih}

Terima kasih kepada Universitas Katolik Widya Mandira melalui LPPM yang telah mendukung penelitian ini.

\section{Daftar Pustaka}

[1] D. Dabas, R. Shegog, G. Ziegler, and J. Lambert, "Avocado (Persea americana) Seed as a Source of Bioactive Phytochemicals," Curr. Pharm. Des., vol. 19 , no. 34 , pp. $6133-6140,2013$, doi: 10.2174/1381612811319340007.

[2] S. Idris, G. I. Ndukwe, and C. E. Gimba, "Preliminary Phytochemical Screening And Antimicrobial Activity Of Seed Extracts Of Persea Americana ( Avocado Pear )," Bajopas., vol. 2, no. 1, pp. 173 176, 2009.

[3] P. Materials, "Trypanocidal Constituents in Plants 5 . 1 ) Evaluation of Some Mexican Plants for Their Trypanocidal Activity and Active Constituents in the Seeds of Persea americana," Biol.Pharm.Bull., vol. 28, no. 7, pp. 1314-1317, 2005.

[4] M. Sangi, M. R. J. Runtuwene, and H. E. I. Simbala, "Analisis Fitokimia Tumbuhan Obat Di Kabupaten Minahasa
Utara," Chem.Prog., vol. 1, no. 1, pp. 47-53, 2008.

[5] G. S. Baud, M. S. Sangi, and H. S. J. Koleangan, "Analisis Senyawa Metabolit Sekunder Dan Uji Toksisitas Ekstrak Etanol Batang Tanaman Patah Tulang (Euphorbia tirucalli L.) Dengan Metode Brine Shrimp Lethality Test (BSLT)." Jurnal Ilmiah Sains., vol 14, no. 2, 2014.

[6] G. R. Ratu Dwi, N. Noviany, N. Arif, and S. Ayu, "Skrining Fitokimia Dan Uji Klt Ekstrak Metanol Beberapa Tumbuhan Yang Berpotensi Sebagai Obat Tradisional Di Lampung," Prosding Semin. Nas. Sains Teknol. VI, no. November, pp. 685-695, 2015.

[7] M. Sayuti, "Pengaruh Perbedaan Metode Ekstraksi, Bagian dan Jenis Pelarut Terhadap Rendemen dan Aktifitas Antioksidan Bambu Laut (Isis hippuris)," Technol. Sci. Eng. J., vol. 1, no. 3, pp. 2549-1601, 2017.

[8] M. Musyarrifah, A. Ilyas, and M. Baharuddin, "Identifikasi Metabolit Sekunder Ekstrak Etil Asetat Biji Alpukat (Persea americana Mill.) dan Uji Toksisitas Terhadap Larva Udang Artemia salina Leach," Al-Kimia, vol. 2, no. 1 , pp. 45-51, 2014, doi: 10.24252/alkimia.v2i1.1637.

[9] L. Puspitasari, D. a. Swastini, and C. I. . Arisanti, "Skrining Fitokimia Ekstrak Etanol 95\% Kulit Buah Manggis (Garcinia mangostana L .)," Garuda Portal, vol. 961, p. 5, 2013.

[10] R. Nugrahani, Y. Andayani, and A. Hakim, "Skrining Fitokimia Dari Ekstrak Buah Buncis (Phaseolus vulgaris L) Dalam Sediaan Serbuk", Jurnal penelitian pendidikan ipa, vol. 2, no. 1, 2016.

[11]R. Retnosari, Sutrisno and K. Handoyo, "Aktivitas Antibakteri Metabolit 
Sekunder dari Ekstrak Metanol Biji Alpukat (Persea americana Mill)," Journal Cis-Trans (JC-T), vol. 1, no.1, pp. 16-21, 2017.

[12] Abubakar, A. Aisyah, and M. Baharuddin, "Isolasi Senyawa Aktif Ekstrak Etanol Biji Alpukat (Persea americana) dan Uji Toksisitas Terhadap Artemia salina Leach," Al-Kimia, vol. 2, no. 1, pp. 25-32, 2014, doi: 10.24252/alkimia.v2i1.1635.

[13]K. Feliana, S. Mursiti, and Harjono, "Isolasi dan Elusidasi Senyawa Flavonoid dari Biji Alpukat (Persea americana Mill.)," Indones. J. Chem. Sci., vol. 7, no. 2, pp. 153-159, 2018.

[14] A. P. Asmara, "Uji Fitokimia Senyawa Metabolit Sekunder Dalam Ekstrak Metanol Bunga Turi Merah (Sesbania grandiflora L . Pers)," Al-Kimia, Vol. 5, no.1, 2017, doi: 10.24252/alkimia.v5i1.2856.

[15] S. D. Marliana and V. Suryanti, "Skrining Fitokimia dan Analisis Kromatografi Lapis Tipis Komponen Kimia Buah Labu Siam (Sechium edule Jacq . Swartz.) dalam Ekstrak Etanol," Biofarmasi, vol. 3, no. 1, pp. 26-31, 2005. 